\title{
Exploration on and Thinking about Aesthetic Infiltration in the Aerobics Teaching in Colleges and Universities
}

\author{
Weidong Ran \\ Sichuan University of Arts and Science, Dazhou, China \\ Email:17347902@qq.com
}

How to cite this paper: Ran, W.D. (2020) Exploration on and Thinking about Aesthetic Infiltration in the Aerobics Teaching in Colleges and Universities. Open Access Library Journal, 7: e6965.

https://doi.org/10.4236/oalib.1106965

Received: November 6, 2020

Accepted: November 20, 2020

Published: November 23, 2020

Copyright $\odot 2020$ by author(s) and Open Access Library Inc.

This work is licensed under the Creative Commons Attribution International License (CC BY 4.0).

http://creativecommons.org/licenses/by/4.0/

\begin{abstract}
Aerobics is deeply loved by students in physical education. With the continuous development of sports in colleges and universities, aerobics has become an important part of physical education. In aerobics teaching in colleges and universities, aesthetic infiltration is the key to promote aerobics teaching. Based on the analysis of the aesthetic characteristics of aerobics and the relationship between aerobics teaching and aesthetic infiltration, this paper discusses the strategies of aesthetic infiltration in aerobics teaching in colleges and universities, in order to provide some reference for the relevant educators of aerobics in colleges and universities.
\end{abstract}

\section{Subject Areas}

Education

\section{Keywords}

Aerobics Teaching in Colleges and Universities, Aesthetic Characteristics,

Relationship, Aesthetic Infiltration

\section{Introduction}

Aerobics teaching in colleges and universities can improve students' comprehensive quality and physical quality. When it infiltrates into the process of aerobics teaching in colleges and universities, aesthetics can effectively attract students' to love aerobics and stimulate their interest in learning. According to the requirements of the reform of physical education, the objective of physical exercise should be to develop comprehensive quality students. The aesthetic infiltra- 
tion in aerobics teaching in colleges and universities is consistent with the idea of the course reform. Only by accelerating the aesthetic infiltration in aerobics teaching, we can improve the development level of sports in colleges and universities.

\section{Aesthetic Characteristics of Aerobics}

\subsection{The Beauty of Movements of Aerobics}

Aerobics teaching focuses on developing students' body coordination ability, which is a process of presenting beauty through coordination of limbs and body. Aerobics fully shows the beauty, health and strength of the human body. Aerobics teaching requires students to practice basic movements in class, including rotation, flexion and extension, swinging, jumping and turning. Through the combination and arrangement of these basic movements, a variety of movements can be formed. In aerobics we pay attention to the beauty of movements. Students are required to complete the difficult gymnastic movements by perfect cooperation of the upper and lower limbs in the learning process. Excellent aerobics athletes can always show the unique charm of aerobics to audiences and the referee through perfect and standardized movements. Aerobics should be complete and uniform, so people can enjoy watching aerobics [1]. In the process of aerobics learning, students should make the aerobics movements accurately and smoothly and show their vitality. As a unique sport, with its own characteristics, aerobics inspires people. Through aerobics, people can express their emotions and bring their emotions into the aerobics movements.

\subsection{Physical Beauty of Aerobics}

Everyone has a love for beauty. Loving beauty is everyone's nature. However, due to congenital factors, the body shape of each person has its own characteristics. Some people are fat, thin, too tall or too short. Some people are not fit. These problems affect people's pursuit of beauty. Aerobics, a sports course in colleges and universities, improves this feature. Through the study of aerobics, students can shape their body. Although the movements of aerobics are simple, the range of movements and the amount of exercise are big in the process of exercise. Students can not only shape their body, but also improve their muscle lines in the exercise, which solves their figure problems caused by congenital conditions. This is also the reason why aerobics teaching in colleges and universities is popular.

\subsection{Beauty of Music of Aerobics}

Each aerobics has a specific music. Students can perform aerobics to the music. Through the rotation and swinging of limbs, aerobics is more beautiful. It is very important to choose music in competitions. Different music can bring people different feelings. From different music and movements, people can deeply understand the connotation of aerobics. A good music can drive the rhythm of the 
person doing aerobics and stimulate his/her emotional expression. If you don't choose good music, aerobics will lose its soul. If aerobics loses music, it will become monotonous and lack of artistic charm. The beautiful aerobics music can bring better artistic effect to audiences.

\subsection{Beauty of Arrangement of Aerobics}

The arrangement of aerobics shows the professional level of physical education teachers in colleges and universities. When arranging aerobics, teachers should pay attention to students' personal conditions and characteristics and set reasonable movements. Only by setting according to the characteristics of students, students can make continuous and smooth movements in the learning process. In aerobics teaching in colleges and universities, teachers can choose movements with moderate difficulty. In the process of display of aerobics, we can also make use of the formation change to show aerobics better. Teachers should know how to arrange aerobics movements and learn how to arrange and show the formation. They should fully listen to students' opinions and integrate their creativity into aerobics [2]. Only by listening to the students' opinions, they can teach better and show all the charm of aerobics.

\subsection{Beauty of Performance of Aerobics}

To evaluate the performance of aerobics, we not only evaluate the movements and postures of aerobics athletes, but also make a comprehensive evaluation of athletes' facial expression, dressing, temperament, etc. The aerobics performance is not evaluated from a single aspect. It is a summary of many aspects. Aerobics can improve the comprehensive quality of students. The evaluation of aerobics is determined by aesthetics. Only by making people feel beautiful as a whole, we can achieve better results.

\subsection{Beauty of Dynamic and Creation of Aerobics}

Aerobics is flexible. It integrates a series of difficult and flexible movements into the music rhythm, so as to show the beauty of youth and vitality. Aerobics has an effect of making people strong. Coupled with its unique ability to display, it shows the vitality of college students. Aerobics is actually a kind of aerobic exercise, which can show the charm of youth. Different aerobics give people different visual enjoyment [3]. The arrangement of each aerobics shows its beauty of creation.

\section{The Relationship between Aerobics Teaching in Colleges and Universities and Aesthetic Infiltration}

With the development and progress of The Times, calisthenics teaching in colleges and universities is becoming more and more popular, while aesthetic penetration is indispensable in calisthenics teaching in colleges and universities. The application of aesthetic penetration in calisthenics in colleges and universities 
has gained much recognition, so it is necessary to give full play to the role of aesthetic penetration. With the continuous improvement of people's aesthetic consciousness, social aesthetics has been formed through practice. The production of magnesium must be accompanied by aesthetic, aesthetic activity is the appreciation of beauty. It forms a new aesthetics in the process of appreciating beauty. Aesthetic penetration is to bring positive influence to the character of the aesthetic subject through various aesthetic activities. The teaching of calisthenics in colleges and universities can improve class quality by using the penetration of aesthetics, which can promote the all-round development of human beings and the whole development of society.

\section{Strategies of Aesthetic Infiltration in Aerobics Teaching in Colleges and Universities}

\subsection{Aesthetic Infiltration of Teaching Objectives}

Make perfect teaching target, can assure teaching to achieve ideal result. The infiltration of aesthetics into teaching objectives not only reflects the value of teaching, but also points out new directions for teaching. The aesthetic penetration of teaching objective is to increase the aesthetic feeling of calisthenics teaching in colleges and universities and to cultivate the aesthetic feeling of students. The teaching objective of aesthetic penetration skills can increase the physical quality of students and exercise the beauty of students' aerobics, and stimulate students' interest in learning, improve classroom enthusiasm. When designing the teaching objectives, calisthenics in colleges and universities can properly integrate music, dance and other elements, carefully design the teaching content on the basis of penetrating aesthetics, and constantly innovate the teaching methods, which can enable students to have a broader understanding of the aesthetic feeling of calisthenics, cultivate students' aesthetic ability, and thus enhance their comprehensive quality.

\subsection{Aesthetic Infiltration of Teaching Content}

The teaching content is the most important in calisthenics teaching. Teachers should not only formulate the perfect teaching purpose, but also optimize the teaching content. Using aesthetic penetration in teaching content can effectively improve teaching efficiency. Calisthenics teachers in colleges and universities should attach importance to the teaching content to ensure that the teaching content is interrelated with aesthetic knowledge, ideological and political knowledge and calisthenics knowledge. Teachers should guide students to learn through the content of textbooks so that students' body and form can achieve good results. Calisthenics teachers in colleges and universities should analyze the physical characteristics of students, so as to better stimulate students' interest and improve class quality. The teaching content should pay attention to modernity, artistry and richness, and make use of various teaching materials. The content should conform to the aesthetic interest of contemporary college stu- 
dents, so as to stimulate students' learning enthusiasm.

\subsection{Aesthetic Infiltration of Teaching Methods and Means}

Aerobics teaching methods and means are an important part of the course, which directly affect classroom efficiency and teaching quality. Integrating aesthetics into teaching methods and means can improve the teaching quality [4]. Therefore, in the process of aerobics teaching in colleges and universities, teachers should learn to beautify their teaching methods and means and actively integrate aesthetic infiltration, so that the classroom education can be carried out normally. Teachers can organize aesthetic teaching activities according to the aesthetic elements of calisthenics. When explaining the basic movements of calisthenics, it is necessary to infiltrate aesthetic knowledge, combine knowledge with ideas, promote students' understanding, let students know the meaning behind the movements, pay attention to details, and infiltrate aesthetics.

\subsection{Establish the Harmonious Interpersonal Relationship}

Teachers and students should establish a harmonious interpersonal relationship. The harmonious relationship between teachers and students can improve the quality of aerobics teaching, so as to complete teaching tasks. The harmonious relationship between teachers and students can improve the students' absorption of the classroom content. Teachers should learn to teach with emotions, make the class not dull or boring, know how to start from students' interest and increase the interest of aerobics teaching.

\subsection{Aesthetic Infiltration of Teaching Environment}

As a teaching element, teaching environment is often neglected. Any teaching activity must have a certain space-time condition, in which both tangible and intangible teaching environment affect the teaching quality. Good teaching environment can help to smoothly carry out aerobics teaching activities. In aerobics teaching, teachers should pay attention to the construction of teaching environment. A good teaching environment can bring a good learning atmosphere for students. Schools can establish special aerobics venues, improve relevant education and teaching facilities, maintain relevant venues and facilities in time, and some introduce some advanced auxiliary teaching equipments of aerobics such as acoustics, and provide good environmental conditions for the aerobics teaching activities [5]. A good external environment can help to improve the quality of teaching and the construction of a good learning atmosphere and beautiful and comfortable environment can strength students' aesthetic consciousness. When they learn aerobics in colleges and universities in a good environment, students can speed up the course progress and improve their active learning ability. For example, when they practice aerobics in the beautiful music environment, students can really enjoy the beauty, so as to participate in the aerobics practice more actively. 


\subsection{Aesthetic Infiltration of Teaching Feedback}

Aesthetic penetration is to educate students through artistic means. Through aesthetic penetration, students are exposed to and subtly influenced to beautify their mind, behavior, language and body. Teaching feedback is very important in the teaching process. Teaching feedback shows students' understanding of the course. The level is the comprehensive response shown after teaching. For aerobics teaching in colleges and universities, teaching feedback is very important. According to the results of teaching feedback, teachers can judge students' mastery of aerobics learning and give targeted guidance [3]. In the process of aerobics teaching, students and teachers should strengthen interaction, and teachers should actively understand students' feedback information and guide students with reasonable teaching methods and means. They should guide students to complete aerobics training with positive and correct means. Only through effective methods, teachers can improve students' learning enthusiasm. They should know how to change students' body posture with aesthetic infiltration and carry out aerobics teaching activities by cultivating students' sense of coordination and rhythm [6]. They should change the students' psychological state and focus on the cultivation of students' sentiment, so that students can truly realize the beauty of aerobics and are willing to learn actively.

\section{Conclusion}

Aerobics is a body-building exercise combining beautiful music and coordinated movements. It has aesthetic and artistic appreciation value, so it is popular among students in colleges and universities. Aesthetic infiltration is required in aerobics teaching in colleges and universities, which can help to improve students' aesthetic ability, aesthetic consciousness and comprehensive quality.

\section{Conflicts of Interest}

The author declares no conflicts of interest regarding the publication of this paper.

\section{References}

[1] Qiao, S. (2019) Thinking about Aesthetic Infiltration in Aerobics Teaching in Colleges and Universities. Boxing and Fighting, No. 20, 20.

[2] Shi, X. (2018) Infiltration of Aesthetic Education in Aerobics Teaching in Colleges and Universities. Emotional Textbook, No. 32, 29.

[3] Zhang, H. (2020) Discussion about the Path of Aesthetic Infiltration Thinking in Aerobics Teaching in Colleges and Universities. Boxing and Fighting, No. 12, 81.

[4] Li, S. (2018) Exploration on the Path of Aesthetic Infiltration in Aerobics Teaching in Colleges and Universities. Vitality, No. 22, 175.

[5] Yin, X. (2018) Preliminary Study on the Practice Method of Aesthetic Infiltration in Aerobics Teaching in Colleges and Universities. Sports Fashion, No. 1, 123-124.

[6] Zhao, N. and Ma, Q. (2016) Research on Effective Ways of Aesthetic Infiltration in Aerobics Teaching in Colleges and Universities. Urban Tutor (Second Half of the Month), No. 8, 195. 